\title{
SOME PRESENT-DAY ISSUES OF PUBLIC UTILITY REGULATION
}

\author{
By Edward W. Bemis,
}

Member of Advisory Board, Valuation Department, Interstate Commerce Commission; Board of Supervising Engineers, Chicago Traction, Chicago, and Director of Valuations for the District of Columbia.

Ten years ago no state save Massachusetts had a commission empowered to deal with municipal utilities, although many cities were beginning to avail themselves of the power they were just discovering they had, or which they might obtain through home rule charters, to demand reasonable rates and service from the public utilities within their borders.

Our cities were discovering that if, through their city governments, they made somewhat extensive investigations of the subject, and acting on such evidence, ordered a reduction of rates, certain important results were likely to follow; either a company would accept the order, in the original or in some modified form, or it would take the case into the courts. There the judges, not wishing to overthrow a coördinate branch of the government, held that the burden of proof was with the company. The latter must convince the court by positive evidence that the city was wrong, and even then if some doubt remained, the court might order a trial of the new rates for a year or more. If the court decided against the city the latter could appeal to the higher courts, just as, if the conditions were reversed, the company could do.

Any return equal to $5 \frac{1}{2}$ per cent or 6 per cent in the East or 7 per cent in the West was usually considered by the court a sufficient return to establish the legality of the city ordinance. Chicago, Indianapolis, Des Moines, and Cedar Rapids, I., were moving in this direction and our public utilities were becoming alarmed. Realizing that monopoly charges are analogous to taxation, they saw no reason why both should not be equally fixed by government and by that government nearest to the business paying the tax or imposing the rate of charge.

Meantime a current toward municipal ownership was setting in. Mayor Johnson, of Cleveland, through a quasi-municipal railway 
with three-cent fares, was forcing a big monopoly of that city to terms which have resulted, even under continued private ownership, in universal three-cent fares throughout the city for the past four years. The recent rapid growth of a competing municipal plant is now greatly reducing electric light and power charges in that progressive city.

In 1907, the famous investigation of municipal ownership in this country and Great Britain by the National Civic Federation resulted in conclusions which $I$ had the honor of assisting to prepare, which read as follows:

We are also of the opinion that all future grants to private companies for the construction and operation of public utilities should be terminable after a certain fixed period, and that meanwhile cities should have the right to purchase the property for operation, lease or sale, paying its fair value.

To carry out these recommendations effectively and to protect the rights of the people, we recommend that the various states should give to their municipalities the authority, upon popular vote under reasonable regulations, to build and operate public utilities, or to build and lease the same, or to take over works already constructed. In no other way can the people be put upon a fair trading basis and obtain from the individual companies such rights as they ought to have. We believe that this provision will tend to make it to the enlightened self-interest of the public utility companies to furnish adequate service upon fair terms, and to this extent will tend to render it unnecessary for the public to take over the existing utilities or to acquire new ones.

This endorsement of the right to have municipal ownership as more effective than any form of regulation was not only approved by men on the commission who were recognized as taking the public point of view, such as Dr. Milo R. Maltbie, of the Public Service Commission, First District, New York; Prof. John R. Commons, of the University of Wisconsin, and of the United States Industrial Commission; Prof. Frank Parsons, of the Boston University Law School; and Dr. Albert Shaw, of the Review of Reviews; but by the then president of the Big Four Railroad, Melville E. Ingalls; President Charles L. Edgar of the Boston Edison; W. J. Clark, of the General Electric; Prof. Frank J. Goodnow, now president of the Johns Hopkins University; Prof. John H. Gray, president of the American Economic Association; Dr. Talcott Williams, formerly editor of the Philadelphia Press; Walter I. Fisher, later Secretary of the Interior, and others. Of the entire committee of twenty-one, only Walton Clark, vice-president of the United Gas Improvement Company, refused to sign this striking statement. 
The public utilities felt that something must be done to prevent cities either from turning to municipal ownership, or from using the power of regulation they already possessed or that they might obtain from state legislatures.

New York state, which had given its cities no powers of regulation, and where municipal ownership was scarcely developed at all, had at this decisive moment a governor who believed that regulation was necessary, and who thought that it could be secured by a state commission with large powers, and with a high grade of men appointed by himself. The commissions which Governor Hughes thus started on their career were composed of strong men, and the example of New York was quickly taken up, under similar conditions, by Governor LaFollette of Wisconsin and Governor Wilson of New Jersey.

With public utilities able to quote such illustrious converts as have been mentioned, the advice of the National Civic Federation commission of 1906-1907, above quoted, and the opportunity of cities through home rule to develop local regulation subject to court review were ignored, or forgotten. Today we have twenty-six states and the District of Columbia where public utilities are regulated by commissions. Scarcely a half-dozen northern states east of Utah have kept out of the procession, and several states might be mentioned in the far West and South, whose utilities are thus regulated. Efforts are being made everywhere else, by the utilities, to obtain similar legislation.

The tendency of a few years ago toward home rule in the regulation of these monopolies has been temporarily checked. Municipal ownership, also, for a time, seemed to be side-tracked, although of late the development of municipal street railways in San Francisco and of municipal electric light and power in Winnipeg and Cleveland, to say nothing of gas and electric light in smaller places, and the recent defeat of the movement for state commissions in Iowa and Minnesota, indicate that state regulation is not found to be as popular as was generally expected.

Meantime the growth of these utilities has been remarkable. The sale of artificial gas has more than doubled in the last ten years. The sale of electric light and power was over four times as much in 1912 as in 1902. The number of passengers carried by street railways more than doubled in the same ten years, while the esti- 
mated number of telephone messages was nearly three times as large in 1912 as in 1902. State commission regulation is now with us in most states. It can give us publicity and uniformity of accounts, tests of service, and many other benefits. We accept it where in vogue, and in this paper we consider how to meet some of the problems involved.

I. The failure of cities to realize that commissions tend to assume the attitude of courts, and to be influenced by the relative weight of evidence, rather than to become independent investigating bodies. Cities must learn that in order to win their cases before a state commission they must prepare their cases even more extensively than is necessary before courts. The latter, as already indicated, almost always declare the burden of proof to be on the utility that opposes the action of a city government. A state commission, whose creation is often avowedly to enable utilities to escape from local control, is not inclined to put the burden of proof upon a utility. Moreover, in some states a city cannot appeal at all to the courts from the decision of a state commission, while companies can always appeal from a commission as freely as a city can appeal from a lower court to a higher court in states where there is no state commission.

It is but human nature for a commission to consider the case of a city as weak where that city does not devote a quarter as much of the intellectual energy and financial resources to the presentation of its view as does the utility in the presentation of its side of the case.

Until cities are ready to wake up, we may well note what Maryland is doing in having a special state attorney to represent complainants in public utility cases. In that state, also, the attorney for the people is sometimes able to secure (as in the Consolidated Gas and Electric Light Case, of Baltimore) state funds for the employment of experts. That, however, could be improved by having the special attorney the direct appointee of the governor. But nothing can well remove the great desirability of direct city participation in a large way in the bringing of cases concerning the locality before the state commission. The evidence of strong local support of a case brought before a commission by a city cannot fail to have weight.

II. The personnel of these commissions is of the greatest importance. The problems presently to be considered require not only 
wide training and breadth of view, but also a high regard for the ethical side of these great questions, and for the public standpoint. A great commissioner, like some of those who have sat on our best commissions, must possess keen powers of analysis and courage in support of the common weal.

If this commission regulation continues, we must select our governors with as much reference to the likelihood of their appointing the right class of public utility commissioners as with reference to all other appointments, or to their general executive policies. The way some of our most famous commissions, starting with splendid material, have steadily degenerated through a succession of appointments pleasing to the politicians or corporations is a significant comment of the oft-quoted argument that commission regulation means the removal of public utilities from politics.

III. The methods of determining the amount of property on which a reasonable return should be earned cannot be too carefully studied by all lovers of fair play. Deprived by our courts of the right to earn on franchise values, our utilities are now everywhere making stupendous efforts to establish before all regulating bodies that the cost of replacement today of the existing property should be the only matter considered, to the entire exclusion of the actual investment or cost of the property. Does the utility occupy, for example, a considerable amount of land which becomes more valuable for sale from year to year although not for public utility purposes? Then the utility demands the right to raise the price of its product or service to keep pace with the increasing value of its land. Has the utility laid mains and conduits in advance of city paving? It now demands the right to increase its charges above what they would otherwise need to be, in order to earn on the cost of cutting through the paving, if an imaginary new plant were now to seek to duplicate these mains and conduits in their present location. Has the price of labor and materials risen? Then up must go the charge for the commodity, even though the buildings and plant were built before the rise in prices. Has the utility a large and profitable business which it obtained through the growth of the community and through canvassing and advertising, properly charged at the time to operating expenses and paid for by the consumers or subscribers? The utility now demands the right to earn, not on the actual cost properly chargeable to capital that was secured to develop 
this income, but on the cost of duplicating it today, in a so-called hypothetical or comparative plant.

The number of unearned increments which can thus be claimed and, alas!- often secured, by a municipal monopoly in a rate case is enough to make Henry George's ideas of the unearned increment of land alone look small indeed.

Far be it from me to reflect upon many engineers who estimate the cost of reproduction of public utilities, but some of our most famous appraisal engineers richly deserve the criticism which the California commission gave last July, in the Monterey Gas and Electric Light Case. After calling attention to the allowance in this case of about 41 per cent for overhead charges and going value, by a prominent firm of engineers, the president of the California commission, John M. Eshleman, stated:

I cannot see why a public tribunal should be criticised merely because of the fact that it is awake to a program that is being conceived and carried forward before its very eyes. That there is a program on the part of large financial concerns interested in public utility securities, particularly in the stock of public utilities for which ordinarily no money has been paid, to exaggerate the value of the property of these public utilities, in my opinion, admits of no doubt. That their procedure is but natural makes it none the less necessary for the public authority to be on his guard. These interests find themselves in the following condition.

The uniform practice has been in the past to construct their properties largely from the proceeds of bonds, and to give as bonus the stock of the corporation, except that which should be withheld by the promoters. Thus the actual property cost originally has been less than the face value of the outstanding bonds-to say nothing of the stock-because under this method bonds are usually sold at less than par. The problem of those in control, therefore, has been to pay the bond interest and gradually build up a value behind the stock which originally, of course, had no value. Now they find themselves halted in this program in many instances, and by valuations by commissions the real relationship between the obligations and the assets is disclosed. Almost frantic endeavors, therefore, are being made to persuade public autbority to place values upon the property for these utilities which shall be sufficient to cover the bonds and leave, if not enough to represent par for the stock, at least enough to represent something, otherwise such stock will be seen to have no value. Furthermore, many of these utilities expect, and I imagine a great many desire, public ownership of their properties. In anticipation of such public ownership, in rate investigations they do not have the rate inquiry alone in mind, but with an eye to the future seek for this reason, too, to import elements of value that have no other foundation than in the desire of the utility to get the highest possible price for its property. 
(City of Monterey vs. Coast Valleys Gas \& Electric Co. desided June 30, 1914, on Rehearing, Decision of July 30, 1914).

How some of our public utilities look upon our present commissions was well illustrated by the remark of the engineer of one of our largest public utility syndicates at a public meeting of a prominent engineering society last year. He said: "I think that commissions are now regarded by the privately-owned properties much like a wild animal that has been tamed. He behaves as a domestic animal at this time, but one cannot tell when the call of the wild may cause him to turn around and bite them." The view of the matter from the public side was vigorously expressed to the speaker at one time by Governor Pingree, of Michigan. Commenting upon a sentence in the annual report just received from the state railroad commission, to the effect that they were glad to announce that their relations with the railroads had been most "friendly" the previous year, the sturdy governor burst out with a formidable expletive, and said: "They have no business to be friendly!" We may not, indeed, wish our commissions to be always on the warpath, but it is still more certain that we do not want them "tamed."

IV. Going value, reserves, and surplus earnings present big problems. Our courts, fortunately, with the exception of New Jersey, have not endorsed a going value, except where early failure to earn a reasonable return was not made up by any later earnings in excess of such a fair rate, and many courts, including the United States supreme court, have not even then admitted a going value in rate cases. The courts that have allowed a going value equivalent to early deficits not made up by later surplus earnings, as in the case of the recent decision of the New York court of appeals, in the Kings County Lighting Company $v$. Wilcox, in March, 1914, have apparently failed to realize that if the company can capitalize in a rate case any deficits in earnings, it is also fair, where a surplus has, on the whole, been earned over and above a fair return, that the public should have the benefit of that surplus.

The Massachusetts Gas and Electric Light Commission contended for this in a very important gas case in Haverhill. That company claimed before the federal court last year that it could not reduce the price of gas to 80 cents as ordered by the state commission, unless it should forego profits on a portion of its property 
which had been built up out of surplus earnings. The state commission frankly admitted this, but contended that the company was not entitled to a full return, and perhaps very little if any return on capital built up out of surplus earnings over and above good dividends. After months of expensive litigation the company, in the early part of this year, dismissed the case before argument, and accepted the price of 80 cents which was in controversy.

In most states, however, companies not only claim a return of 8 per cent or more on their surplus, but a similar return on the funds they have collected from the subscriber or user, to meet depreciation, even though the amount of yearly addition to the depreciation fund has been determined by the amount necessary in case no interest is earned.

If an old and well established company has poor credit, on account of watered stock and bonds, and so has had to pay a considerable discount in order to sell its securities, it asks a correspondingly higher price from the public utility to make up for its own lack of credit. If it prefers to sell 5 per cent bonds at a discount of 5 or 10 per cent instead of $5 \frac{1}{2}$ per cent bonds at par, it still demands an 8 per cent return on the discount paid, as well as on the money secured.

It will at once be seen that the public needs, in order to meet these complex problems, not only its best legal, engineering and accounting talent, but the services of its best economists and students of public policy.

$\mathrm{V}$. The apportionment of rates between various classes of electric consumers should not always be according to cost of service. Small consumers may well be asked, as in gas and water, to pay less than cost, but the limits of time set for this paper prevent the discussion of this important subject.

VI. The virtual if not legal validation of all our watered securities under the guise of state approval of new securities is another serious menace. It is possible to conceive of helpful state control and publicity with respect to new securities, but what is actually going on is startling: Many of our commissions, without any investigation at all, in some states, and in other states with no investigation worthy of the name, are giving a perfunctory approval to the issue of hundreds of millions of dollars of securities. These are at once advertised as approved by the state. They are usually thrown 
into a common pot with the old stocks or bonds of the same class. Either false hopes are aroused among investors, or the danger arises that the courts will hold that a genuine class of innocent investors in watered securities has been created by state law. The courts of late years have come to ignore, as of no significance, outstanding stocks and bonds in rate cases. What they may do under these crude laws and cruder enforcement of them is problematical. One state commission has approved hundreds of millions of securities without any investigation. Another thus recently approved $\$ 26,000,000$ on the first day of its life as a commission.

VII. The relation of regulation to municipal ownership. Commission regulation must be divorced from interference with the charges and administration of municipal plants, except in the requirement of publicity and uniformity of accounts. As long as cities, through proper state supervision of accounts, know what their plants are doing, they should be free to run them at a profit or loss, and with such an apportionment of rates between different classes of consumers, as local public opinion demands. The right of cities to follow Cleveland's example in establishing its own utilities must be left as free and unrestrained as throughout Ohio, and during the past year in Illinois. Sandusky, Ohio, would have waited for years to secure through a state commission what the people, through a mere threat of municipal competition, have secured this year from a private company, viz., a maximum charge of 7 cents and a secondary charge of 4 cents for electric light.

VIII. Syndicates of capital must be met with syndicates of cities. A dozen syndicates such as The United Gas Improvement Company, The American Light and Traction Company, Stone and Webster, and those controlled by Billesby, Doherty, and Insull, seem bound upon putting any amount of money into a local rate case in order, as was baldly stated three years ago in Des Moines, "to teach city councils a lesson," and to secure from commissions and courts, before it is too late, the endorsement of corporation theories with respect to going value, replacement costs, rate of return, etc.

The leading expert for privately owned gas companies, Mr. Humphreys, told the National Association of such companies, The American Gas Institute, last month: "It is up to the Institute to educate these commissions."

City attorneys, no matter how strong as lawyers in general 
practice, are not in office long enough to warrant such specialization upon public utility matters as is practicable for our larger corporation attorneys. Through fellowship in the common purpose, the attorney of one utility syndicate is kept informed of the testimony taken in cases involving other syndicates. Each city, on the other hand, approaches the subject of regulation as a new proposition. With the multiplicity of commission and court decisions and public utility discussions before engineering and economic bodies, it is becoming every month more difficult for a new student of the problem to put himself abreast of developments in the short time of preparation possible to him.

The time was not entirely ripe for the movement in 1900 , when it was my fortune to assist in starting the bureau of economic research, in New York City, with the help of V. Everett Macy, R. Fulton Cutting, Tom L. Johnson, W. J. Gaynor, Bird S. Coler, George H. Shibley, John R. Commons, and others, out of which organization developed, in other hands, the quite different bureau of municipal research. The time seems now at hand, for an organization such as is here proposed. If the movement is to have any permanent result, other than general education, which of course is in itself valuable, it must be kept absolutely divorced from the building up of any man or administration. To this proposition those who have called us together agree. The organization must likewise be effectively officered and strongly supported.

That such a gathering as this could be brought together without being financed by any public utility is itself evidence of the growth, during the past five years, toward a settlement of the great problems we are now considering. May we prove equal to the task of dealing with them with that disinterestedness, sanity and good sense which the times and these problems demand. 